Vol. 2 | No. 2 | 2021 | Hal. 137-141

\title{
EDUKASI MASYARAKAT MELALUI PROGRAM SOSIALISASI VAKSINASI DI MASA PANDEMI COVID-19
}

\author{
Abdullah Syakur Novianto*, Adib Qosim Masrukhan, Ikbar Zakariya, Iksan, Alwi \\ Muhamad, Navila Laila Wardani, Cynthia Renita Putri, Zukhruf Dinnisa', Riza \\ Humayroh, Iqbal Burhanuddin Maulidy, Syamsul Arifin \\ Fakultas Ekonomi dan Bisnis, Universitas Islam Malang \\ *korespondensi email: asnovianto@unisma.ac.id
}

\begin{abstract}
ABSTRAK
Virus Corona marupakan virus yang berbahaya dan mudah menyerang orang tua dan anakanak yang usia dini. Eksistensi covid-19 di indonesia tidak hanya menyebar pada lingkungan perkotaan, melainkan dapat terinfeksi dilingkungan yang terperincir atau pendesaanpendesaan yang di pergunungan. Masyarakat desa kalipare merupakan desa yang berada di Kabupaten Malang, juga terdampak bahayanya virus corona sehingga mulai aktivitas sekolahan, pengajian, dan keluar rumah mulai dibatasi demi mematahkan rantai tersebarnya covid-19. KSM Tematik UNISMA berkesempatan untuk mengabdi di desa kalipare dengan beberapa program yang akan dilaksanakan selama sebulan. Program yang utama adalah program penanggulan covid-19, seperti membagikan masker, memasang poster-poster, sosialisasi vaksinisai dan pembelajaran terhadap anak-anak.
\end{abstract}

Kata Kunci: covid-19; program edukasi masyarakat

\section{PENDAHULUAN}

Covid-19 merupakan virus corona yang muncul mulai dari akhir tahun 2019 di kota Wuhan China. Virus yang membuat masyarakat ketakuatan dan memenjarakan diri dari rumah masing-masing, membuat banyak orang mati setaip hari (Yuliana, 2020). Tidak hanya negara china saja yang terjangkit dengan dengan virus ini, bahkan sampai negara-nagara maju pun terinfeksi virus ini, seperti Amerika Serikat, Australia, dan lain-lain. Virus yang tidak terlihat oleh mata, kehadiranya disetiap daerah bagaikan angin yang bertiup (Yunus \& Rezki, 2020). Tersebarnya virus ini tidak hanya pada dunia nyata, bahkan sampai dunia maya pun tersebar dengan cara menginformasikan segala informasi kematian atas covid tersebut. Meskipun saat ini (2021), virus tidak terdengar menakutkan seperti tahun kemarin, namun masyarakat tetap dihimbau untuk tetap waspada dan mematuhi segala protokol kesehatan demi kesehatan lahiriyah (Masruroh \& Hayati, 2021).

Covid-19 tidak hanya berkeliaran di perkotaan, namun dipendesaan juga. Karena virus ini adalah virus bawaan dari orang yang berada didaerah kena virus (Rahmawati et al., 2021). Dan virus ini tidak bisa dijangkau oleh mata, namun terasa dalam diri manusia dengan salah satu cirinya adalah bebatuk yg keras. Mungkin batuk yang seperti itu akan dianggap biasa oleh orang lain, namun, bisa jadi batuk itu badalah batuk karena virus. Oleh kerena itu, mulai pihak pemerintah dan medis, sibuk mengawasi masyarakat agar masayarakat dapat menjaga jarak dengan semaksimal mungkin. Tim medis juga sibuk, 
mempersiapkan penawaran dari covid ini, agar covid ini tidak menular dengan menyebar di banyak orang (Paramadina et al., 2021).

Desa Kalipare secara geografis memiliki luas 2.085,52 Ha, sebelah utara desa Kalipare berbatasan dengan sungai brantas kecamatan Sumberpucung, arah ke selatan berbatasan dengan Desa Putukrejo dan arah ke timur berbatasan dengan Desa Sumberpetung, Adapun sebelah barat berbatasan dengan Sukowilangun. Desa Kalipare ini memiliki 7 Dusun, diantaranya yaitu, Dusun Sumberkombang, Dusun Kaliasem, Dusun Ngembul, Dusun Krajan, Dusun Kauman, Dusun Sumbermaron, Dusun Pitrang.

Adapun potensi Desa Kalipare, yakni sektor pertanian yang fokus pada tanaman pangan, terutama subsektor Pertanian dan Perkebunan, yakni jagung, padi, tebu dan abai. Data di ambil bulan Deseber 2020. Dimana jagung mencapai 7 ton, padi mencapai 7,5 ton, tebu 770 ton, cabai 1,5 ton, sehingga kelompok KSM memiliki inisiatif untuk membantu warga dalam mengembangkan perekonomian warga melalui penanaman cabai di salahsatu lahan warga Dusun pitrang.

Berdasarkan latar belakang masalah diatas, KSM Tematik Unisma yang memiliki personal berbagai kelompok melakukan edukasi di masyarakat Desa Kalipare, Kabupaten Malang dalam melakukan penanggulangan penyebaran Covid-19 melalui program. Dalam mencegah penularan dan penyebaran Covid-19 ini, kelompok KSM ini mengedukasi masyarakat melalui pemberian pemahaman tentang Covid-19, pentingnya penggunaan masker saat berpergian, pentingnya memakai handsanitizer saat berada di luar rumah dan pentingnya mencuci tangan yang benar.

Selain membantu masyarakat dalam membasmi Covid-19, kelompok ini juga menyediakan pernak pernik protokol kesehatan seperti poster, banner kampanye pencegahan covid dan tempat cuci tangan beserta handsoap di lingkungan desa kalipare dalam Program. Oleh karena itu, pada artikel kali ini akan membahas mengenai kegiatan KSM Tematik di Desa Kalipare Kab Malang melalui edukasi kepada masyarakat serta pemahaman mengenai pentingnya mengikuti aturan protokol kesehatan dalam penanggulangan Covid-19.

\section{METODE}

Berdasarkan hasil observasi dan wawancara ditemukan banyak ketidaksesuaian terhadap perilaku pencegahan penyebaran Covid-19 dan kurang aktif dalam mengajar siswa-siswa di Desa Kalipare karena masih terjadi Kurangnya pengetahuan masyarakat tentang Covid-19, sehingga program unggulan difokuskan dalam meningkatkan pengetahuan dan merubah sikap masyarakat Desa Kalipare terhadap bahaya Covid-19 yaitu melalui pendidikan. Program yang dijalankan antara lain Sosialisai Vaksinisasi dalam bentuk kolaborasi bersama pemuda-pemudi omah poduktif dengan harapan kedepan dapat menginspirasi untuk menyampaikan kepada masyarakat luas.

\section{HASIL DAN PEMBAHASAN}

Program KSM Tematik Unisma telah terlaksana meskipun tidak maksimal, karena berbagai macam kendala di Desa Kalipare. Namun, program KSM ini telah menjadi landasan dalam mengedukasi masyarakat ditengah pandemi Covid-19, dengan sambutan dan antusias masyarakat desa kalipare dalam menyelenggarakan setiap program KSM dapat berjalan dengan lancar.

Salah satu program KSM Tematik Unisma di Desa Kalipare yang telah diselenggarakan selama sebulan dengan melaksanakan sosialisasi vaksinisasi kepada masyarakat merupakan kegiatan yang sangat penting untuk dilaksanakan oleh kelompok KSM Tematik Unisma, karena vaksin juga sebagai usaha pemerintah dalam menanggulangin 
penyeberan covid di lingkungan masyarakat. Masyarakat desa kalipare marupakan desa yang jauh dari perkotaan sehingga kurang mengetahui tentang vaksin.

Dalam menyelenggarakan kegiatan sosialisasi vaksin, dijelaskan mulai bahaya covid19 , cara mencegah agar tidak terinfeksi covid, terutama menjelaskan pentingnya masyarakat untuk melakukan vaksinisas demi terwujudnya kehidupan masyarakat yang bebas dari virus corona.

Vaksinasi merupakan kegiatan imunitas dalam diri seseorang untuk mencegah berbagai penyakit, terutama penyakit yang mematikan. Beberapa penyakit yang dapat dicegah dengan vaksinasi adalah: polio, difteri, tetanus, pertusis, tuberkulosis, campak, hepatitis $B$, hepatitis $A$, influenza, meningitis akibat infeksi hemofilus tipe $B$, tergantung dari sifat dan jenis vaksinnya.

Vaksin merupakan penawar dari virus ini. Dengan vaksin ini fisik orang-orang dapat bertahan dari serangan virus. Vaksin ini sebagai solusi dalam beraktivitas diluar rumah, namun juga tidak terlepas agar tetap menjalankan 3 M (Menjaga jarak, Mencuci tangan, Memakai masker).

Tidak bisa di pungkirin juga, bahwa seluruh masyarakat khusunya masyarakat pendesaan juga merasa tidak yakin bahwa vaksin adalah solusi terbaik untuk menjaga ketebalan diri masyarakat desa. Namun, tugas kita sebagai orang yang paham terkait hal ini, memiliki kewajiban dalam memberikan pemahaman kepada masyarakat desa bahwa sangat penting sekali untuk melakukan vaksinisasi. Karena dengan vaksinisasi ini, masyarakat dapat beraktivitas di luar rumah dengan maksimal.

Dengan usaha dalam memberikan pemahaman, bahwa vaksin ini sangat penting dalam menjaga fisik denga stabil. Maka, desa akan sehat, Kuat, dan terjaga dari covid-19. Vaksin ini juga tidak hanya menjadi penyelamat bagi diri sendiri, namun juga, akan memberikan kenyaman bagi orang-orang sekitar kita.

Jenis vaksin yang digunakan untuk mencegah penyakit tergantung pada beberapa faktor antara lain sifat alami penyakit, cara infeksi, variasi karakteristik organisme, dan sifat respon imun. Untuk penyakit yang disebabkan oleh eksotoksin seperti difteria maka digunakan toksoid sebagai vaksin.

Vaksin polio oral digunakan untuk menimbulkan kekebalan mukosa saluran cerna. Vaksin influenzae perlu dimodifikasi secara reguler sesuai perubahan virus untuk menimbulkan perlindungan terhadap jenis virus yang sedang prevalen. Vaksin polio mengandung 3 strain virus untuk melindungi terhadap 3 strain virus polio liar.

Keadaan respon imun juga turut menentukan, seperti vaksin campak tidak diberikan sampai umur 9 bulan karena adanya antibodi ibu yang mungkin masih beredar dalam darah bayi. Vaksin Hemophilus influenzae b (Hib) dan vaksin pneumokokus akan lebih efektif bila diberikan sebagai vaksin konjugat protein dibanding vaksin polisakarida pada anak kurang dari 2 tahun.

Dirangkum dari situs resmi Pusat Pengendalian dan Pencegahan Penyakit (CDC), berikut adalah beberapa efek samping dari vaksin Covid-19 antara lain (1) Rasa sakit dan (2) Pembengkakan. Selain itu, efek samping vaksin Covid-19 juga dapat menyebabkan flu atau demam menyerang seseorang saat beraktivitas sehari-hari. Namun, efek samping tersebut akan hilang dalam beberapa hari. Selain itu, sebagian besar vaksin Covid-19 membutuhkan dua suntikan untuk bekerja.

Tubuh membutuhkan waktu untuk membangun perlindungan setelah vaksinasi apa pun. Vaksin Covid-19, yang membutuhkan dua suntikan, mungkin tidak melindungi seseorang dari infeksi virus corona sampai satu atau dua minggu setelah suntikan kedua. Untuk itu, penting bagi semua individu, termasuk yang sudah mendapat vaksin Covid-19, untuk terus mematuhi protokol kesehatan guna mencegah penularan virus corona. 
Untuk mengurangi rasa sakit dan ketidaknyamanan setelah injeksi vaksin Covid-19, maka dapat mengoleskan kain bersih, sejuk, dan lembab ke area tersebut. Juga, gerakkan lengan untuk mengurangi rasa sakit. Sedangkan jika sedang demam, itu bisa minum banyak cairan untuk memperbaiki kondisi tubuh.

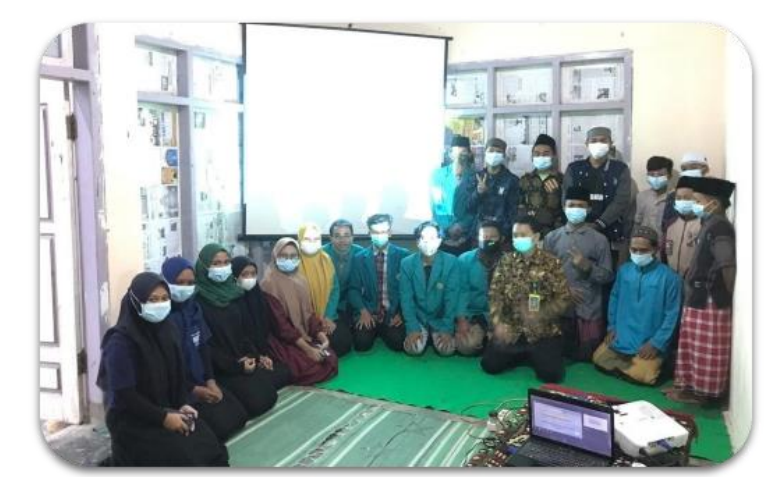

Gambar 1. Suasana sosialisasi vaksinasi bersama komunitas omah produktif kalipare

KSM Tematik Unisma juga menyediakan masker untuk masyarakat. Salah satu penanggulan covid-19 adalah memakai masker di saat berpergian atau keluar dari rumah, karena covid ini barawal dari batuk yang tidak biasa. Masker ini guna untuk melindungi hidung dan mulut, supaya udara yang berbaya disekitarnya tidak menyerang kondisi badanya. Dalam pembagian masker ini, dilakukan ketika bertemu dengan masyarakat yang tidak membawa masker saat bepergian, juga dilakukan ketika ada kegiatan-kegiatan pengajian di musholah.

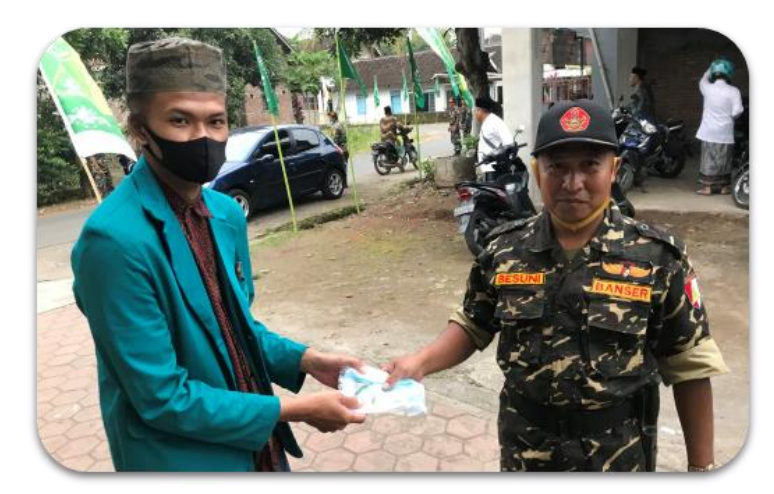

Gambar 2. Bagi masker pada acara harlah NU

Pemasangan poster tentang pencegahan penyebaran Covid-19 di Fasilitas umum. Pemasangan poster ini sangat penting dilakukan, karena dengan poster-poster tersebut masyarakat dapat memahami dan sesalu partisipasi dalam menjaga kesehatan individu, kesehatan masyarakat, dan kesehatan Desa. Poster ini dipasang mulai danmasjid, musholah, dan tempat-tempat keramaian seperti pasar. 


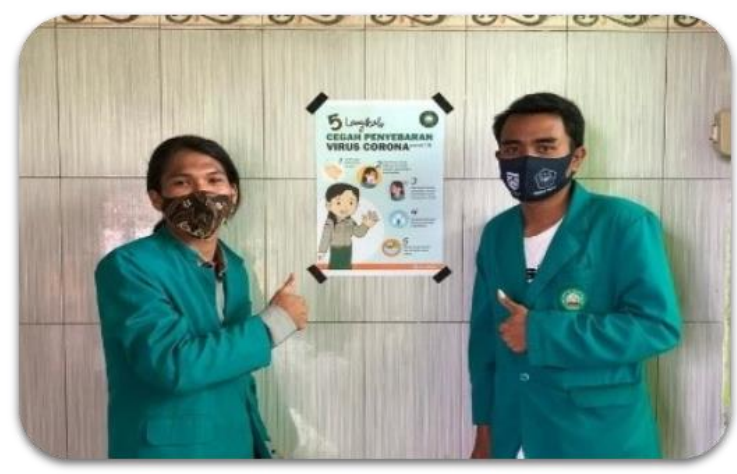

Gambar 3. Pemasangan poster Covid-19

\section{KESIMPULAN}

KSM Tematik UNISMA membuat program yang dapat mengkontribusikan kepada masyarakat Kalipare sebagai edukasi masayarakat ditengah pandemi Covid-19. Desa Kalipare merupakan desa yang tidak terlepas berbagai macam aktivitas, mulai aktivitas bercocok tanam di ladang atau sawa sampai jual-beli dipasar, yang tentunya harus bisa berantisipasi dengan memakai masker ketika sedang keluar rumah, mecuci tangan dgn bersih.

Oleh karena demikian, program KSM Tematik Unisma diatas telah mengedukasikan kehidupan masyarakat, meskipun kurang optimal dalam melaksanakan secara keselurahanya. Namu juga, dalam kegiatan selama sebulan ini telah mengajarkan kekompok KSM untuk lebih efekti, dan produktif dalam melaksanakan kegiatan-kegiatan yang melibatkan masyarakat.

Dalam menjalankan segala program kelompok KSM ini tentunya tidak bisa lepas dari kekurangan, karena setiap pemahaman yang mungkin dianggap benar oleh yang memberikan pemahaman, namun belum tentu bagi yang sedang memahami pemahamanya. Oleh karena itu, tentunya kelompok ini mengharapkan masukkan dan kritik baik tulisan maupun dalam membuat program dari bapa/Ibu Dosen.

\section{DAFTAR RUJUKAN}

Masruroh, \& Hayati, N. (2021). Media poster sebagai sarana edukasi masyarakat dalam upaya pencegahan covid-19. Jurnal Inovasi Hasil Pengabdian Masyarakat (JIPEMAS), 4(36), 169-176. https://doi.org/10.33474/jipemas.v4i2.9207

Paramadina, D. R., Hartanto, N., Syarifuddin, A., Pradifta, R. M., Tania, F. F., Ramadhan, F., Putri, I. S., Triani, F., Putra, A. H., Anwar, M. S., Nurdiansyah, M. F., Pratama, G. A., Ilmi, M. A. N., \& Fatahillah, A. I. (2021). Edukasi bahaya covid-19 daerah pedesaan di era new normal. Jurnal Pembelajaran Pemberdayaan Masyarakat (JP2M), 2(1), 35-40. https://doi.org/10.33474/jp2m.v2i1.8908

Rahmawati, N. M., Putri, S. N. Y., Burohman, D. A., Kelilauw, A. S., Wijaya, I. K., Lamury, F. F., Fatrunisah, I., Marwah, S., Zahro, A., Ayun, F. Q., \& Atika, N. (2021). Sosialisasi peduli lingkungan dan pencegahan covid -19 melalui pengadaan tempat sampah, hand sanitizer, dan tempat cuci tangan. Jurnal Pembelajaran Pemberdayaa Masyarakat (JP2M), 2(1), 19-28. https://doi.org/10.33474/jp2m.v2i1.8722

Yuliana. (2020). Corona virus diseases (Covid-19); Sebuah tinjauan literatur. Wellness and Healthy Magazine, 2(1), 187-192. https://doi.org/10.30604/well.95212020

Yunus, N. R., \& Rezki, A. (2020). Kebijakan Pemberlakuan Lock Down Sebagai Antisipasi Penyebaran Corona Virus Covid-19. Salam: Jurnal Sosial Dan Budaya Syar-I, 7(3), 227238. https://doi.org/https://doi.org/10.15408/sjsbs.v7i3.15083 